\title{
The Effectiveness of Using Human Maps Learning Media on Learning Motivation in IPA Basic Concepts II
}

\author{
Ila Israwaty ${ }^{1}$, Nurjannah ${ }^{2}$, Natriani Syam ${ }^{3}$ \\ \{ila.israwaty@unm.ac.id ${ }^{1}$, nur.jannah@unm.ac.id ${ }^{2}$, natriani.syam@unm.ac.id ${ }^{3}$ \} \\ 1,2,3Program Studi PGSD Fakultas Ilmu Pendidikan Universitas Negeri Makassar, Indonesia
}

\begin{abstract}
The purpose of this study was to determine the effectiveness of the use of human maps learning media on learning motivation in science concept 2 basic subjects in Semester 4 . The problem formulation in this study is whether the use of human maps learning media is effective on learning motivation in science concept 2 . This research uses a quantitative approach to the type of research that is experimental research design using Quasi Experimental in the form of Nonequivalent Pretest-Posttest Control Group Design. Data analysis techniques used in this study are descriptive statistical analysis and inferential statistical analysis. The results of hypothesis testing using the Paired Sample Ttest obtained significance of $0.0(0.00<0.05)$ and tcount $>$ ttable $(6.835>1.699)$. Thus it can be concluded that $\mathrm{Ha}$ is accepted, namely the use of human maps learning media is effective against learning motivation in the Basic Concepts of Science 2 students in Semester 4 Campus V UNM Parepare.
\end{abstract}

Keywords : learning media, learning motivation, human maps

\section{Introduction}

In the current era of globalization, it is developing very rapidly. One of the thoughts of globalization in the field of Science and Technology (Science and Technology). To be accepted, we need people who have human resources through education. Education is a process to help humans to develop the potential that exists in themselves, so as to be able to make all the changing times that will require them to think logically, systematically, critically, creatively, intelligently, openly, and have curiosity.

The world of education is inseparable from the learning process which includes teachers / lecturers, students, and learning environments that influence one another. Media is one of the supporting factors for the achievement of learning objectives. This relates to the use of appropriate and varied media in the learning process so that it can increase learning motivation and can reduce student passivity. The teacher / lecturer in carrying out his role in the learning process needs tools that can convey information to students. Arsyad (2014) states that the use of instructional media in the learning process can arouse new desires and interests, as well as arouse motivation and stimuli for learning [2].

Jucius in Sumantri (2015) argues that motivation as an activity gives impetus to someone or yourself to take the desired activity. This is stimulated by a variety of needs. Someone who has the motivation to do something tends to give greater attention to the object. But if the object does not cause a sense of pleasure then a person will not have the motivation for the 
object [16]. This is in line with the theory put forward by Mc. Donald in Sardiman (2016) which states that motivation is a change of energy in a person (person) that is marked by the emergence of feelings and is preceded by a response to the existence of goals [11]. Motivation is a relatively permanent trait in a person. This motivation has a great influence on the learning process because with motivation a person will do something he likes, however, if without motivation someone will not do something well.

Motivation is a factor that influences success in the learning process. If a student has a great learning motivation, students will quickly understand and remember it. Student learning motivation can affect student activity in the learning process. This is in accordance with the times and technological developments, which in the learning process requires students to be more active. Board Game as a technological tool can be used as a medium to assist in the learning process.

The use of learning media can be applied wherever possible in all subjects, including Physics, Biology, Natural Sciences, Mathematics, Social Sciences, and others. The Basic Concept of Natural Science 2 is one of the courses that has long been taught in the curriculum majoring in Elementary School Teacher Education. This course is theoretical and practical taught in semester 4 with a credit score of 3 credits. In this Natural Science 2 Basic Concept course there are materials / objects that need to be observed so that the material can be more easily understood by students. Therefore, this course also consists of practical activities. However, due to limited tools and materials as well as situations and conditions that do not allow for practicum, sometimes it becomes an obstacle in this course. Meanwhile, students also certainly lack the enthusiasm and motivation to learn when lecturers only explain conventional subject matter.

As explained above that learning media can be applied as far as possible in all subjects. With the learning media in this case the Human Maps learning media is expected to increase student motivation. Human Maps learning media can make learning more interesting and abstract material can be visualized in the form of visual media (pictures) on board games that are made with attention to aesthetics so that students' motivation to learn and build knowledge becomes easier to do. Human Maps learning media is packaged as attractive as possible by using the concept of the snake and ladder game so that students can easily understand a material. In addition, the Human Maps learning media can make learning more fun because it uses game methods.

Based on the description, the researcher is interested in conducting research with the title "The Effectiveness of the Use of Human Maps Learning Media on Learning Motivation in Science Concept Basic Subjects 2 Semester 4 Students of Campus V UNM Parepare".

\section{Media Use}

In essence, learning is a communication process, namely the process of delivering messages from the source to the recipient of the message. One of the communication processes in learning is the media. As according to Sadiman (Susanto, 2014: 314) states that: "Learning media are all things that can be used to channel messages from the sender to the recipient so that it can stimulate the thoughts, feelings, and interests and attention of students in such a way that the learning process occurs"[19]

The above theory is not much different from the theory put forward by Rusman (2012: 160) which states that "instructional media is a messenger technology that can be used for learning purposes and is a physical means of conveying subject matter". In the learning process, the media is used by the teacher as an intermediary to convey information or 
messages to students. For this reason, it is necessary to know the characteristics of good learning media [10]. There are three characteristics of learning media according to Gerlach and Ely in Arsyad (2014), namely:

a. Fixative features, describing the ability of the media to record, store, preserve and reconstruct an event or object that can be ordered and rearranged with media such as photography, video tape, audio tape, computer disks, and film.

b. Manipulative features, events that take days, can be presented to students in two or three minutes with time-lapse recording technique.

c. Distributive characteristics, allowing an object or event to be transported through space, and simultaneously these events are presented to a large number of students with relatively similar stimulus experiences about the event [2].

Technically, the learning media functions as a learning resource. In this sentence the source of learning implies the meaning of being a distributor, a conveyor, a liaison, and others. According to Susanto (2014) briefly explains the use of instructional media as follows:

a. Clarify the message so it is not too verbalistic

b. Overcoming the limitations of space, time, energy and sense power

c. Gives a passion for learning, more direct interaction between students and learning resources

d. Allows children to learn independently according to their talents and visual, auditory and kinesthetic abilities

e. Giving the same stimulation, equalizing experience and giving rise to the same perception [19].

Meanwhile according to Sukiman (2012) briefly explains the function of learning media as follows:

a. Learning media can clarify the presentation of messages and information so as to facilitate and improve the process and learning outcomes.

b. Learning media can improve and direct children so that it can lead to learning motivation, more direct interaction between students and their environment, and the possibility of students to learn on their own according to their abilities and interests.

c. Learning media can overcome the limitations of the senses, space and time [15].

\section{Basic Concepts of Natural Sciences 2.}

Natural Sciences (IPA) is knowledge about the universe with all its contents. In general Abruscato (Bundu, 2010: 18) suggests three definitions of natural science are:

a. Natural sciences are a number of processes of systematic activity of gathering information about the world around,

b. Science is knowledge gained through a process of certain activities, and

c. Science is characterized by the values and attitudes of scientists using scientific processes in gaining knowledge [3].

Based on the above understanding it can be concluded that learning science not only consists of a collection of knowledge or a variety of facts and principles in the form of declarative knowledge, but consists of an active process of using the mind to study natural phenomena that can not be explained in the surrounding environment students so that science learning is emphasized on developing students 'creativity in managing their thinking and can connect one phenomenon with other phenomena in their environment, which certainly can strengthen students' understanding in understanding the observed object. 
Carin and Sund in a book written by Bundu (2010: 22) stated that "there are three criteria that must be fulfilled by a theory in science, namely observation, prediction, and experiment" [3]. The three theoretical criteria in science can be described as follows:

a. Able to explain phenomena that occur through observation (observation).

b. Able to explain events that will occur (predictions).

c. Can be tested for truth through similar experiments (experiments).

\section{The Use of Learning Media}

Technically, the learning media functions as a learning resource. In this sentence the source of learning implies the meaning of being a distributor, a conveyor, a liaison, and others. According to Susanto (2014) briefly explains the use of instructional media as follows:

a. Clarify the message so it is not too verbalistic

b. Overcoming the limitations of space, time, energy and sense power

c. Gives a passion for learning, more direct interaction between students and learning resources

d. Allows children to learn independently according to their talents and visual, auditory and kinesthetic abilities

e. Giving the same stimulation, equalizing experience and giving rise to the same perception [19].

Meanwhile according to Sukiman (2012) briefly explains the function of learning media as follows:

a. Learning media can clarify the presentation of messages and information so as to facilitate and improve the process and learning outcomes.

b. Learning media can improve and direct children so that it can lead to learning motivation, more direct interaction between students and their environment, and the possibility of students to learn on their own according to their abilities and interests.

c. Learning media can overcome the limitations of the senses, space and time [15].

\section{Motivation to learn}

Motivation means there is an inner urge to do something. In line with the opinion of Djumingin (2011) which states that motivation comes from the word motive, it means as an effort to encourage someone to do something [4]. This is in line with the opinion expressed by Winkel in Uno (2010) explaining the meaning of motives namely the driving force in a person to carry out certain activities, in order to achieve certain goals [20]. So, motivation is an internal condition as an active driving force. Donald in Sardiman (2016: 73) argues that "motivation is a change in energy in a person which is marked by the emergence of feelings and preceded by responses to the existence of goals" [11].

\section{Motivation Function}

There are four functions of motivation according to Djumingin (2011), namely:
a. Encourage people to do
b. Determine the direction of the action, ie towards the goal to be achieved
c. Selecting an action, i.e. determining an immediate and must be done, and
d. Set aside actions that are not beneficial for the purpose [4].

\section{Form of Motivation}


There are several forms of motivation. Sardiman (2016) argues that forms of motivation are:

a. Gives Numbers

b. Gifts

c. Competition or competition

d. Ego-Involment

e. Give a test

f. Know the results

g. Praise

h. Punishment

i. Desire to learn

j. Interests [11]

\section{Research Method}

\section{a. Research Approaches and Types}

In general, the research method is defined as a scientific way to obtain data with specific purposes and uses. The research approach used by prospective researchers is a quantitative approach. Sumarni (2012: 106) argues that "the quantitative approach is a process of finding knowledge that uses data in the form of numbers as a means of finding information about what we want to know" [17].

Based on the opinion above, the quantitative approach method used to determine the effectiveness of the use of Human Maps learning media on learning motivation in the Basic Concepts of Science 2 students of Semester 4 Campus V UNM Parepare.

\section{b. Research Variables and Research Design}

The variables in the study consisted of two, namely:

1) Bound Variable: motivation to learn in the basic concepts of Natural Sciences 2

2) Independent variables: the use of Human Maps learning media.

The research design used in this study is Quasy Experimental in the form of Nonequivalent Pretest-Posttest Control Group Design. Lestari and Yudhanegara (2015) stated that in the design of this study, two classes were given a pretest $(\mathrm{O})$ to find out their initial conditions. The pretest given to the experimental class is the same as the pretest given to the control class. . During the research, the first class was given treatment $(\mathrm{X})$ and the other classes were treated as usual before. The treated class was made into the experimental class and the group treated as usual was carried out as a control group. Then at the end of the study, both classes were given a post-test $(\mathrm{O})$ to see how the results were [7].

Table 1. Research Design The Nonequivalent Pretest-Posttest Control Group Design

\begin{tabular}{cccc}
\hline Kelas & Pretest & Treatment & Posttest \\
\hline $\mathrm{E}$ & $\mathrm{O}_{1}$ & $\mathrm{X}$ & $\mathrm{O}_{2}$ \\
$\mathrm{~K}$ & $\mathrm{O}_{3}$ & & $\mathrm{O}_{4}$ \\
\hline
\end{tabular}

Keterangan :

E : Experiment Class

$\mathrm{K}$ : Control Class

$\mathrm{O}_{1}:$ Pretest (Experiment Class)

$\mathrm{O}_{2}:$ Posttest (Experiment Class)

$\mathrm{O}_{3}:$ Pretest (Control Class) 
$\mathrm{O}_{4}:$ Posttest (Control Class)

$\mathrm{X}$ : Learning by the experimental method

\section{c. Definition of Variable Operations}

1) Human Maps Learning Media

The learning media referred to in this study is one type of learning media in the form of Board Games called Human Maps. This learning media is designed to resemble a snake and ladder game. This learning media can make the learning atmosphere more enjoyable because in its use there are games resembling snakes and ladders so as to be able to arouse student learning motivation. In addition, this learning media can also increase interaction between teacher-student and student-student. This Human Maps learning media contains material about the respiratory system in humans. In this learning media there are pictures along with information relating to the respiratory system in humans that are designed attractively.

2) Student Learning Motivation in Science Concept Basic Subjects 2

Learning motivation is defined in this research is the existence of internal and external encouragement to students to follow the learning process. In this research, what you want to see is the motivation of students to study the basic concepts of Science 2 after treatment. Student learning motivation is measured using a questionnaire in the form of a number of statements filled out by students.

\section{d. Population and Sample}

The population in this study were all students of Semester 4 Campus V UNM Parepare. The sampling technique used in this study is cluster random sampling technique According to Sugiyono (2009) that cluster random sampling is a sampling technique whose population does not consist of individuals but groups of individuals taken at random [12]. So, the sample in this study is students Semester 4 Campus V UNM Parepare which includes C12.A, C12.B, C12.C and C12.D.

\section{e. Data Collection Techniques and Procedures}

1) Data Collection Techniques

1) Questionnaire (Questionnaire)

The main data collection technique used in this study is the Questionnaire (Questionnaire). According to Sugiyono (2017: 199) "questionnaire or questionnaire is a data collection technique that is done by giving a set of questions or written statements to respondents to be answered" [13]. With a questionnaire a person can be known about the situation / personal data, experience, knowledge, attitudes, opinions, and so on. Questionnaire is used because it is practical, saving time, effort and cost.

2) Documentation

Sukardi (2015) states that documentation is a data collection technique for finding information that has an important role and needs to get important attention for researchers. Examples include notes, curriculum vitae, environmental conditions, agenda and so on [14]. This technique is used to get the data needed as a basis for obtaining documentation data in the form of the names of Semester 4 students in Campus V UNM Parepare. This technique is also used to obtain data in the form of photos about the learning process by using the Human Maps learning media at Campus V UNM Parepare needed in this study. 
2) Data Collection Procedure

Data collection was carried out four times in learning the basic concepts of Natural Sciences 2. The first meeting giving pretest in the experimental class and the second meeting giving the pretest in the control class. The third meeting giving treatment (action) in the experimental class and posttest and the fourth meeting giving posttest in the control class. The meeting is held in $3 \times 50$ minutes. The time spent is adjusted to the learning of Basic Concepts of Natural Sciences 2 at Campus V UNM Parepare. The details of the procedure are as follows:

a) Pretest

Pretest activities are carried out before treatment with the aim of knowing the students' initial abilities before being given treatment (treatment).

b) Treatment

Provision of treatment in the form of the application of experimental methods in the implementation of learning activities in the class.

3) Posttest

At this stage, students are given a test (evaluation) after finishing giving treatment (treatment)

\section{f. Data Analysis Technique}

Analysis of research data aims to provide an explanation and information from the data that has been collected. Quantitative data analysis was performed using statistics with the help of the Statistical Package for Social Science (SPSS) version 22 program. The data analysis techniques used in this study are as follows:

1) Descriptive Statistics Analysis

Descriptive statistical analysis aims to determine student learning motivation through describing the characteristics of the distribution of achievement scores of students' learning motivation toward the subject of Science 2 Basic Concepts using Human Maps learning media consisting of mean, median, mode, standard deviation, grades highest, lowest value and variants.

2) Inferential Statistical Analysis

Inferential statistical analysis is intended to test the research hypothesis. Before testing the hypothesis, the data prerequisite test is performed. In the data prerequisite test performed Data Normality Test and Data Homogeneity Test.

While the hypothesis test Paired Sample t-test was performed.

a) Normality Test

Before analyzing a hypothesis test, it is first necessary to know whether the data meets the statistical use requirements that will be used in hypothesis testing. Data normality test is done to find out whether the data obtained from the subject is normally distributed or not. Normality test in this study was carried out using the Statistical Pachage for Social Science (SPSS) version 22 system using the Kolmogorov Smirnof method. Test criteria: $\mathrm{P}>\alpha$, where $\alpha$ $=0.05$. Data is normally distributed if the significance value obtained is greater than $\alpha=0.05$.

b) Homogeneity Test

Homogeneity test is performed to determine whether the two groups of data obtained have the same variance or are homogeneous. Homogeneity test in this study uses the Statistical Pachage for Social Science (SPSS) version 22 program with the test criteria: $\mathrm{P}>\alpha$ where $\alpha=0.05$. The data is declared homogeneous if the significance value obtained is greater than $\alpha=0.05$. 
c) Hypothesis Test

Based on the description contained in the background, literature review, and framework, the hypothesis can be described as follows:

The statistical hypothesis:

$\mathrm{H}_{0}: \mu 1=\mu 2 \quad$ Ha: $\mu 1 \neq \mu 2$

Information :

$\mu 1 \quad$ : Average student learning motivation before being given treatment.

$\mu 2$ : Average student learning motivation results after being given treatment.

$\mathrm{H}_{0} \quad$ : There is no difference in motivation to learn Basic Concepts of Natural Sciences 2 semester 4 students

Ha : There are differences in motivation to learn the Basic Concept of Science 2 semester 4 students of Campus V UNM Parepare between before and after the use of the Human Maps learning media.

Hypothesis rejection criteria:

$\mathrm{H}_{0}$ is rejected if $\mathrm{P}<\alpha$, where $\alpha=0.05$

$\mathrm{H}_{0}$ is rejected if tcount $>$ ttable

\section{Results Of Research and Discussion}

\section{Research Results}

a. Descriptive Statistics Results

1) Description of Student Motivation for Semester 4 Campus V Parepare UNM Taught by Using Human Maps Learning Media.

a) Initial Score (Pretest) Motivation of Student Learning Experiment Class Before Given Treatment in the form of Human Maps Learning Media

Table 2. Description of Initial Scores (Pretest) Student Learning Motivation in Experimental Classes Before Being Given Treatment in the form of Human Maps Learning Media

\begin{tabular}{cc}
\hline Statistic & Statistic Value \\
\hline Sample Size & 20 \\
\hline Mean & 83,15 \\
\hline Median & 81,50 \\
\hline Modus & 76,00 \\
\hline Standard Deviation & 11,17 \\
\hline Minimum & 62,00 \\
\hline Maximum & 107,00 \\
\hline
\end{tabular}

Table 3. Distribution of Frequency Initial Scores Motivation for Student Learning

Experimental Class

\begin{tabular}{ccc}
\hline Interval & Frequency & Relative Frequency \\
\hline $103-120$ & 2 & $10,00 \%$ \\
\hline S $85-102$ & 6 & $30,00 \%$ \\
\hline $67-84$ & 10 & $50,00 \%$ \\
\hline $49-66$ & 2 & $10,00 \%$ \\
\hline$\leq 48$ & 0 & $0,00 \%$ \\
\hline
\end{tabular}


b) Final Score (Posttest) Motivation of Student Learning Experiment Classes After Being Given Treatment in the form of Human Maps Learning Media

Table 4. Description of the Final Score (Posttest) Student Learning Motivation in Experiment Classes After Being Given Treatment in the form of Human Maps Learning Media

\begin{tabular}{cc}
\hline Statistic & Statistic Value \\
\hline Sample size & 20 \\
\hline Mean & 92,95 \\
\hline Median & 89,50 \\
\hline Modus & 79,00 \\
\hline Standard Deviation & 11,91 \\
\hline Minimun & 79,00 \\
\hline Maximum & 115,00
\end{tabular}

Table 5. Distribution of Frequency Final Score Motivation of Student Learning Experiment Class

\begin{tabular}{ccc}
\hline Interval & Frequency & Relative Frequency \\
\hline $103-120$ & 6 & $30,00 \%$ \\
\hline $85-102$ & 8 & $40,00 \%$ \\
\hline $67-84$ & 6 & $30,00 \%$ \\
\hline $49-66$ & 0 & $0,00 \%$ \\
\hline$\leq 48$ & 0 & $0,00 \%$ \\
\hline
\end{tabular}

2) Overview of Student Motivation in Semester 4 Campus V Parepare UNM being taught without using learning media

a) Initial Score (Pretest) Learning Motivation of Control Class Students Before Being Taught by Conventional Method

Table 6. Description of Initial Scores (Pretest) Student Learning Motivation in the Control Class Before Being Given a Treatment in the Form of Conventional Methods

\begin{tabular}{cc}
\hline Statistic & Statistic Value \\
\hline Sample size & 20 \\
\hline Mean & 84,15 \\
\hline Median & 82,00 \\
\hline Modus & 79,00 \\
\hline Standard Deviation & 11,48 \\
\hline Minimun & 63,00 \\
\hline Maximum & 106,00
\end{tabular}

Table 7. Frequency Distribution of Initial Scores Motivation for Students Learning Control Class

\begin{tabular}{ccc}
\hline Interval & Frequency & Relative Frequency \\
\hline $103-120$ & 2 & $10,00 \%$ \\
\hline $85-102$ & 7 & $35,00 \%$ \\
\hline $67-84$ & 10 & $50,00 \%$ \\
\hline $49-66$ & 1 & $5,00 \%$ \\
\hline$\leq 48$ & 0 & $0,00 \%$ \\
\hline
\end{tabular}


b) Final Score (Posttest) Learning Motivation of Class Control Students After Being Given Treatment in the form of Conventional Methods.

Table 8. Description of the Final Score (Posttest) Student Learning Motivation in the Control Class After Being Given a Treatment in the Form of Conventional Methods

\begin{tabular}{cc}
\hline Statistic & Statistic Value \\
\hline Sample size & 20 \\
\hline Mean & 87,30 \\
\hline Median & 84,50 \\
\hline Modus & 82,00 \\
\hline Standard Deviation & 9,80 \\
\hline Minimun & 68 \\
\hline Maximum & 110 \\
\hline
\end{tabular}

Table 9. Distribution of Frequency Final Score Learning Motivation for Students in Control Class

\begin{tabular}{ccc}
\hline Interval & Frequency & Relative Frequency \\
\hline $103-120$ & 2 & $10,00 \%$ \\
\hline $85-102$ & 8 & $40,00 \%$ \\
\hline $67-84$ & 10 & $50,00 \%$ \\
\hline $49-66$ & 0 & $0,00 \%$ \\
\hline$\leq 48$ & 0 & $0,00 \%$ \\
\hline
\end{tabular}

Table 10. Motivation to Learn the Basic Concepst of Natural Sains two on the Subject of the Respiratory Siystem and Digestive System in Humans in the Experimental Class and Control Class

\begin{tabular}{cccccc}
\hline \multirow{2}{*}{ Score } & \multirow{2}{*}{ Category } & \multicolumn{2}{c}{ Experiment } & \multicolumn{2}{c}{ Control } \\
\cline { 3 - 6 } & & Frequency & Percent (\%) & Frequency & Percent (\%) \\
\hline $103-120$ & Very High & 6 & $30,00 \%$ & 2 & $10,00 \%$ \\
$85-102$ & High & 8 & $40,00 \%$ & 8 & $40,00 \%$ \\
$67-84$ & Medium & 6 & $30,00 \%$ & 10 & $50,00 \%$ \\
$49-66$ & Low & 0 & $0,00 \%$ & 0 & $0,00 \%$ \\
$\leq 48$ & Very Low & 0 & $0,00 \%$ & 0 & $0,00 \%$ \\
\hline
\end{tabular}

\section{Results of Inferential Statistics}

a. $\quad$ Testing Data Requirements

Requirements that must be met before testing the hypothesis is to test for normality and homogeneity. All calculations are carried out using the Statistical Package for Social Sciences (SPSS) computer program Version 22.

Table 11. Test Data Normality by Using SPSS Version 22

\begin{tabular}{cc}
\hline \multicolumn{2}{c}{ Experiment Class $\alpha(0.05)$} \\
\hline Pretest & Posttest \\
\hline$\rho$-Value $>\alpha$ & $\rho$-Value $>\alpha$ \\
$0,200>0.05$ & $0,184>0.05$ \\
\hline
\end{tabular}


Based on the results of data analysis using SPSS version 22, it can be concluded that the sample is normally distributed because the value obtained is greater than the significant level of 0.05 . So the normality test is fulfilled so this analysis uses parametric statistics.

b. Hypothesis Test

Based on testing the analysis requirements, the experimental class pretest and posttest values were normally distributed and the variance of the pretest and posttest values of the sample was declared homogeneous. Next to test the hypothesis used Paired Sample T-Test.

Hypothesis zero (H0): There is no difference in motivation to learn Basic Concepts of Science 2 Semester 4 Students in Campus V UNM Parepare between before and after the use of human maps learning media.

Alternative Hypothesis (Ha): There are differences in motivation to learn Basic Concepts of Science 2 Semester 4 Students in Campus V UNM Parepare between before and after the use of human maps learning media. Decision making is based on the test results obtained, namely:

a. Based on significance:

1) If the Significance value or Sig (2-tailed) $>0.05$, then HO is accepted and Ha is rejected.

2) If the Significance value or Sig (2-tailed) $<0.05$, then H0 is rejected and Ha is accepted.

Based on the tcount:

1) If the value of $\mathrm{t}$ is $<\mathrm{t}$ table, then $\mathrm{H} 0$ is accepted and $\mathrm{Ha}$ is rejected.

2) If the value of $\mathrm{t}>\mathrm{t}$ table, then $\mathrm{HO}$ is rejected and $\mathrm{Ha}$ is accepted.

Paired Sample T-test results obtained significance of $0.00(0.00<0.05)$ and tcount $>$ ttable $(6.835>1.699)$. Based on the two criteria above, it can be concluded that HO is rejected and Ha is accepted, which means there are differences in motivation to learn the Basic Concepts of Science 2 semester 4 students of Campus V UNM Parepare between before and after the use of human maps learning media. Based on these results it can be concluded that the use of human maps learning media influences learning motivation in the Basic Concepts of Science 2 students in Semester 4 Campus V UNM Parepare. For complete data, see Appendix 2.

\section{Discussion}

Based on the results of descriptive statistical analysis using the SPSS version 22 program, the lowest pretest scores of the experimental and control classes were 63.00 and 62.00 while the highest pretest scores were the experimental and control classes 107.00 and 106.00. This shows that students in both classes have a learning motivation in the Basic Concepts of Science 2 concept which is almost the same before getting treatment. Then, after treatment was given, the highest and lowest posttest scores of the experimental class were respectively 115 and 79, while the highest and lowest posttest scores of the control class were 110 and 68 respectively. This shows that the posttest scores of the experimental class higher than the control class posttest score.

The results of the analysis show that students' learning motivation in the experimental class after being given a treatment (posttest) is higher than before being given treatment and the changes that occur in the experimental class are greater when compared to the changes that occur in the control class. This is because the experimental class is given treatment in the form of a human maps learning media where in the learning process students feel motivated to learn because the learning media can stimulate students' thoughts, feelings, interests and attention to 
focus more on paying attention to the learning so that the learning process takes place optimally. This is in accordance with the theory put forward by Sadiman (Susanto, 2014: 314) states that:

Learning media are all things that can be used to channel messages from the sender to the recipient so that they can stimulate the thoughts, feelings, and interests and attention of students in such a way that the learning process occurs. The learning process using human maps learning media in this study begins with the formation of groups. Students are divided into several groups with a total of 4 people per group. Furthermore, the lecturer distributes the human maps learning media to each group. This way of playing media is like a snake and ladder game where everyone has the opportunity to take the question card and if he answers correctly he can advance according to the instructions on the card. And vice versa, if he is not able to answer the question correctly then he must step back a few steps in accordance with the instructions on the question card.

This media is designed as attractive as possible where in this media is equipped with pictures about the material being studied namely material respiratory system and digestive system in humans. In addition, this media is also equipped with images that indicate we can go straight up the stairs and pictures that indicate we have to go down like a snake and ladder game.

The learning process using human maps learning media can arouse learning enthusiasm for students because the use of this learning media uses the concept of games so that students are actively involved in playing games and students can interact directly with learning resources. Students in the learning process are given the opportunity to independently find out for themselves the material learned through games so that lecturers no longer need to explain the material being studied in detail. Lecturers only direct students. In addition, learning media can also provide the same experiences and perceptions for students. This is consistent with the theory put forward by Susanto (2014) to explain briefly the use of instructional media as follows:

a. Clarify the message so it is not too verbalistic

b. Overcoming the limitations of space, time, energy and sense power

c. Cause a passion for learning, more direct interaction between students and learning resources

d. Allows children to learn independently according to their talents and visual, auditory and kinesthetic abilities.

e. Giving the same stimulation, equalizing experience and giving rise to the same perception [19].

The learning motivation table of students' posttest scores in the experimental class and the control class shows that the number of students in the experimental class belonging to the category of learning motivation is very high in the subject of Basic Concepts of Natural Sciences 2 on the subject of the respiratory system and digestive system in humans when more than the number students in the control class belonging to the category of very high learning motivation.

The data shows that students who are taught using human maps learning media have increased motivation to learn higher when compared to students who are taught using conventional methods. This is because the use of instructional media can clarify the presentation of material because in this learning media there are text and images. The text and images in this learning media are integrated and designed in a way that is as interesting as possible so that it creates motivation for learning for students. In addition, the use of this learning media can make students actively involved in their own learning through games in 
groups and students can also interact directly with learning resources. This is in line with the theory put forward by Sukiman (2012) to briefly explain the function of instructional media as follows: Learning media can clarify the presentation of messages and information so as to facilitate and improve the process and learning outcomes. Learning media can enhance and direct the child so that it can lead to learning motivation, more direct interaction between students and their environment, and the possibility of students to learn on their own according to their abilities and interests. Learning media can overcome the limitations of the senses, space and time [15].

Statistical results of inferential analysis are performed for hypothesis testing, which was previously tested for data analysis requirements. The results of testing the data analysis requirements state that the pretest and posttest data of the experimental class are normally distributed. Likewise with homogeneity testing, the variance of pretest data and posttest data of the experimental class is declared homogeneous. The results of hypothesis testing using the Paired Sample T-test show that $\mathrm{H}_{0}$ is rejected and $\mathrm{Ha}$ is accepted, which means there are differences in motivation to learn the Basic Concepts of Science 2 semester 4 students of Campus V UNM Parepare between before and after the use of human maps learning media. Based on these results it can be concluded that the human maps learning media influences learning motivation in the Basic Concepts of Science 2 students in Semester 4 Campus V UNM Parepare.

\section{Conclusion}

Based on the results of data analysis and discussion it can be concluded that the average value of students' learning motivation in semester 4 of UNM Parepare campus before being given treatment in the form of human maps learning media has increased after giving treatment. Hypothesis test results using the Paired Sample T-test showed Sig (2-tailed) $<0.05$ and tcount $>\mathrm{t}$ table. Based on the two criteria above, it can be concluded that the use of human maps learning media influences learning motivation in the basic concept subjects of Science 2 Semester 4 Students in Campus V UNM Parepare. 


\section{References}

[1] Ahmadi, Rulam. Pengantar Pendidikan Asas \& Filasafat Pendidikan. Yokgyakarta: ArRuzz Media(2014)

[2] Arsyad. Media Pembelajaran. Jakarta: PT. Raja Grafindo(2014)

[3] Bundu, Patta. 2010. Asesmen Pembelajaran IPA. Makassar: Badan Penerbit $\mathrm{UNM}(2010)$

[4] Djumingin, Sulastriningsih. Strategi dan Aplikasi Model Pembelajaran Inovatif Bahasa dan Sastra. Makassar: Badan Penerbit Universitas Negeri Makassar (2011)

[5] Emzir. Metodologi Penelitian Pendidikan Kuantitatif \& Kualitatif. Jakarta: PT Raja Grafindo Persada (2015)

[6] Kompri. Motivasi Pembelajaran Perspektif Guru dan Siswa. Bandung: PT Remaja Rosdakarya(2016)

[7] Lestari, Karunia Eka dan Yudhanegara, Mokhammad Ridwan. Penelitian Pendidikan Matematika. Bandung: PT Refika Aditama(2015)

[8] Maolani, Rukaesih A. \& Ucu, Cahyana. Metodologi Penelitian Pendidikan. Jakarta: PT Raja Grafindo Persada (2015)

[9] Noor, Juliansyah. Metodologi Penelitian Skripsi, Tesis, Disertasi, \& Karya Ilmiah. Jakarta: Kencana Prenada Media Group (2011)

[10] Rusman. Belajar dan Pembelajaran Berbasis Komputer Mengembangkan Profesionalisme Guru Abad 21. Bandung: Alfabeta (2012)

[11] Sardiman. Interaksi dan Motivasi Belajar Mengajar. Jakarta: Rajawali Pers (2016)

[12] Sugiyono. Metode Penelitian Pendidikan Pendekatan Kuantitatif, Kualitatif, dan R\&D. Bandung: Alfabeta (2009)

[13] ----------. Metode Penelitian Pendidikan Pendekatan Kuantitatif, Kualitatif, dan R\&D. Bandung: Alfabeta (2017)

[14] Sukardi. Metodologi Penelitian Pendidikan Kompetensi dan Praktiknya. Jakarta: PT Bumi Aksara (2013)

[15] Sukiman. Pengembangan Media Pembelajaran. Yogyakarta: Pedagogia (2012)

[16] Sumantri, Mohamad Syarif. Strategi Pembelajaran Teori dan Praktik di Tngkat Pendidikan Dasar. Jakarta: PT Rajagrafindo Persada (2015)

[17] Sumarni, Sri. Metodologi Penelitian Pendidikan. Yogyakarta: Insan Madani (2012)

[18] Susanto, Ahmad. Teori Belajar dan Pembelajaran di Sekolah Dasar. Jakarta: Kencana Prenamedia Group (2013)

[19]-----------------. Pengembangan Pembelajaran IPS di Sekolah Dasar. Jakarta: Prenada Media Group (2014)

[20]Uno, Hamzah. Teori Motivasi dan Pengukurannya. Jakarta: Bumi Aksara (2010) 